\title{
One-stage surgical treatment of neglected simultaneous bilateral locked posterior dislocation of shoulder: a case report and literature review
}

\author{
İhmal edilmiş iki taraflı eş zamanlı kilitli arkaya omuz çıkığının tek seansta cerrahi tedavisi: \\ Olgu sunumu ve literatür derlemesi
}

\author{
Nurzat Elmalı, MD.,' Zeki Taşdemir, MD., ${ }^{2}$ Fevzi Sağlam, MD., ${ }^{2}$ Deniz Gülabi, MD., ${ }^{2}$ Özgür Baysal, MD. ${ }^{2}$ \\ 1Department of Orthopedics and Traumatology, Bezmialem Vakıf University, İstanbul, Turkey \\ ${ }^{2}$ Department of Orthopedics and Traumatology, Dr. Lütfi Kırdar Kartal Training and Research Hospital, İstanbul, Turkey
}

\begin{abstract}
Simultaneous bilateral locked posterior dislocation of the shoulder is a rare injury. Herein, we present a 59-year-old male case with a three-month history of an irreducible locked bilateral posterior dislocation of the shoulders with an associated large impression fracture on the anteromedial aspect of both humeral heads after a grand mal type epileptic seizure. Plain X-ray and computed tomograph revealed a defect on the right side more than $40 \%$ of the articular surface, and on the left side, $30 \%$. He was treated with a one-stage operation with a reconstruction of femoral head osteochondral allograft on the right side and transfer of the osteotomized tuberculum minus with its attached subscapularis tendon into the defect (modified McLaughlin technique) on the left side. At 14 months during follow-up, the patient was pain-free with stable shoulder joints and satisfactory functionality.
\end{abstract}

Keywords: Bilateral shoulder dislocation; locked dislocation; treatment.

Bilateral posterior or anterior dislocations of the shoulder joint are rare. ${ }^{[1,2]}$ Most posterior shoulder dislocations have been attributed to high energy trauma, seizures or electroconvulsive therapy. ${ }^{[3]}$ Misdiagnosis of this injury may occur in 50\% to $79 \%$ of patients, most commonly due to lack of clear clinical signs and accurate imaging study findings. ${ }^{[4,5]}$ Computed tomography can quantify the involvement of the articular surface of the humeral head and identify fractures of the tuberosity, surgical neck, or glenoid. In addition, magnetic resonance imaging has been widely used to reveal posterior cuff tears and posterior avulsion lesions. ${ }^{[6]}$ Treatment

\section{$\ddot{O} Z$}

İki taraflı eş zamanlı kilitli arkaya omuz çıkı ğı oldukça nadirdir. Bu yazıda grand mal tipi epilepsi nöbetinden sonra her iki humerus başının anteromedial yüzeyinde büyük impresyon kırığı ile birlikte redükte edilemeyen iki taraflı arkaya kilitli omuz çıkı̆̆ı gelişen 59 yaşında erkek bir olgu sunuldu. Direkt grafiler ve bilgisayarlı tomografide sağ tarafta artiküler yüzeyin \%40'ından fazla, sol tarafta $\% 30$ oranında defekt saptandı. Hastaya tek seansta să̆ tarafına femur başı osteokondral allogrefti ile ve kendisine tutunan subskapularis tendon ile birlikte osteotomize edilen tüberkulum minus'un defekt içerisine transferi (modifiye McLaughlin tekniği) uygulandı. On dört aylık izlemde hasta ağrısız, omuz eklemi stabil ve fonksiyonları tatminkar idi.

Anahtar sözcükler: İki taraflı omuz çıkığı; kilitli çıkık; tedavi.

of neglected posterior dislocation of the shoulder is challenging.

This report describes successful treatment of a simultaneous locked bilateral posterior dislocation of the shoulder with an associated large impression fracture of both articular surfaces of the humeral head due to an epileptic seizure. Defect of the humeral head on right side which was more than $40 \%$ of the articular surface was treated with osteochondral allograft femoral head, while a lesser articular defect was treated with the modified McLaughlin technique using absorbable suture anchors in the left side in a one-stage operation.

- Received: November 04, 2014 Accepted: January 25, 2015

- Correspondence: Nurzat Elmalı, M.D. Bezmialem Vakıf Üniversitesi Ortopedi ve Travmatoloji Anabilim Dalı, 34093 Fatih, İstanbul, Turkey. Tel: +90 532 - 4359129 Fax: +90 212 - 5332326 e-mail: nelmali@hotmail.com 

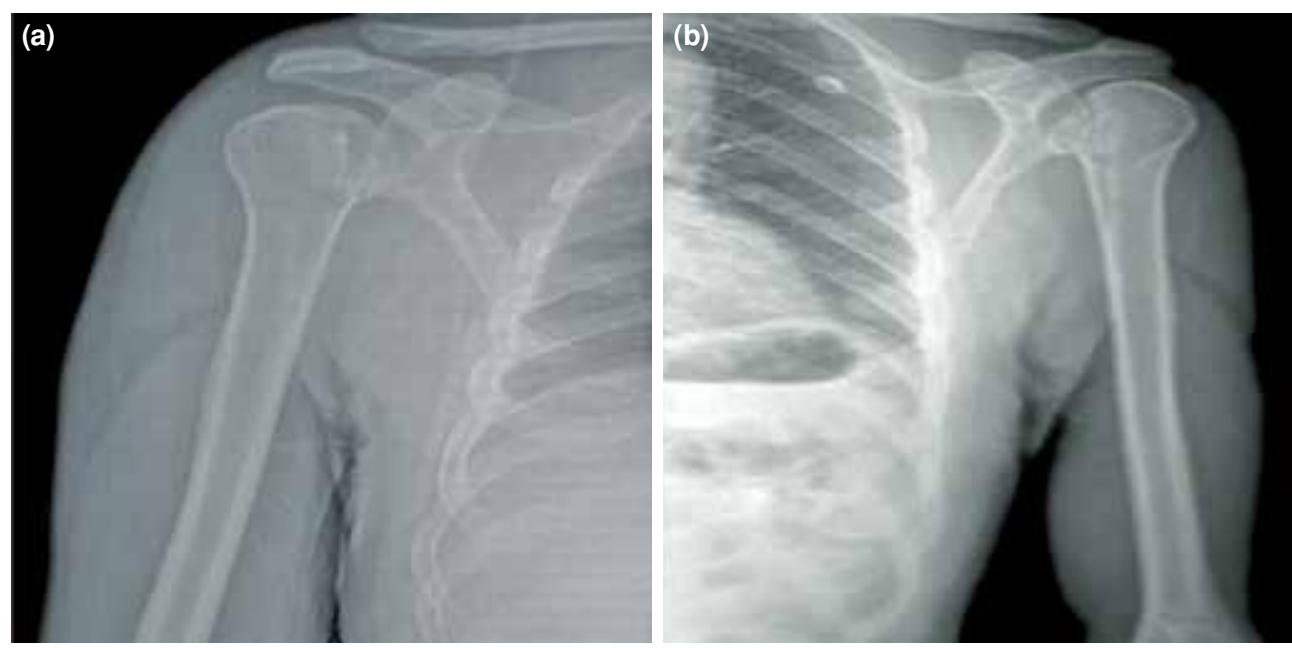

Figure 1. Anteroposterior radiographs of the right (a) and left (b) shoulders showing the internally rotated humerus and the characteristic "lightbulb sign" of its proximal part.

\section{CASE REPORT}

A 59-year-old homeless man presented with a three-month history of severe bilateral shoulder pain and restriction of motion after a grand mal seizure. Physical examination showed that the normal contours of both shoulders were lost and an increased anterior prominence of the coracoid was visible. He had old bilateral shoulder ecchymoses and restricted and painful movements in all ranges of both shoulder joints. Active flexion of the shoulder was 35 degree and external rotation was impossible. The neurovascular examination was normal. He reported no history of shoulder trauma or surgery. Anteroposterior radiographs of the shoulders showed loss of the glenohumeral joint line parallelism and both shoulders were fixed in internal rotation with a reverse Hill-Sachs lesion of the humeral head, slightly larger on the right side (Figure 1a, b). Computed tomography delineated the locked posterior shoulder dislocation. The impaction fracture of the anteromedial humeral head was measured on scans performed in the horizontal plane at the level of the largest diameter of the head and was expressed in percentage of the projected total articular surface. The defects were of more than $40 \%$ involvement of the articular surface on the right humeral head and approximately $30 \%$ on the left (Figure 2a, b). Therefore, osteochondral allograft of the humeral head and modified McLaughlin technique using absorbable suture anchors were scheduled as a one-stage operation for the right and left side, respectively. An informed consent was obtained from the patient for the proposed treatment after full explanation of the risks, complications, and benefits of surgery, and salvage of the shoulder versus shoulder arthroplasty.

The patient was placed in the beach chair position and the right glenohumeral joint was initially
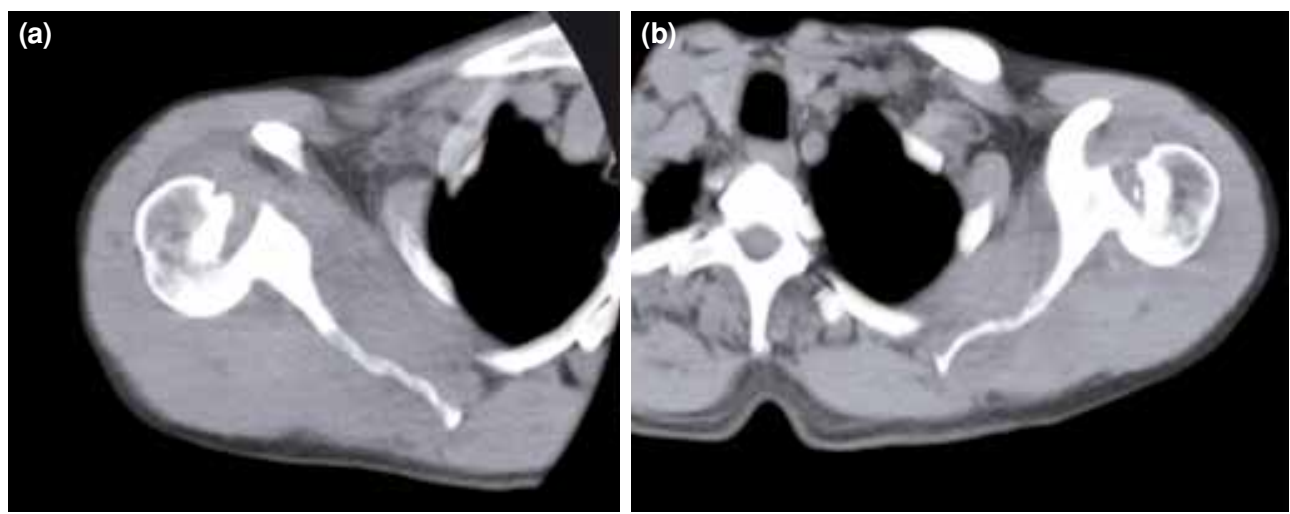

Figure 2. Axial computed tomography of the right (a) and left (b) shoulders showing locked posterior fracture-dislocations. The anteromedial defects were of more than $40 \%$ involvement of the articular surface on the right humeral head and $30 \%$ on the left. 
assessed using a deltopectoral approach under general anesthesia. The axillary nerve was protected throughout mobilization of the subscapularis and the inferior aspect of the capsule. The humeral head and glenoid were exposed after a longitudinal capsulotomy. The humeral head was found to be dislocated posteriorly. After meticulous removal of any bony or cartilaginous tissue, the joint was thoroughly irrigated. The joint was unstable even with a few degrees of internal rotation. For the large reverse Hill-Sachs lesion, reconstruction of the humeral head with an allogeneic bone was planned. A cryopreserved femoral head was used. The allograft was contoured to fit the segmental defect and to restore the original sphericity of the humeral head. The graft was fixed with two $3.5 \mathrm{~mm}$ cancellousbone lag screws (Synthes, Waldenburg, Switzerland). The humeral head was reduced using a Cobb elevator with a gentle manoeuvre, paying attention to avoid further damage to the humeral head and glenoid. Then, the humeral head was reduced. The anterior aspect of the capsule was repaired. Stable fixation was evaluated intraoperatively and the injury site was closed in layers using one-suction drain. The surgery team, then, focused on the left shoulder. In the same patient position and through the standard deltopectoral approach, the lesser tuberosity was osteotomized with the subscapularis and capsule attached and tagged at its musculotendinous junction with a non-absorbable \#2 fiber wire suture (Arthrex Inc., Naples, Florida, USA) and was elevated to expose the humeral head and glenoid. The humeral head was also dislocated posteriorly. Approximately a 30\% reverse Hill-Sachs lesion was detected. The shape of the humeral head was restored by packing the defect with morselized femoral head allograft. Before packing the allograft into the defect, two absorbable $5.5 \mathrm{~mm}$ suture anchors (Bio-Corkscrew FT; Arthrex Inc.) were inserted at the base of the defect. Next, the lesser tuberosity was transferred together with its attached subscapularis muscle into the anteromedial defect according to the McLaughlin technique modified by Hawkins et al. ${ }^{[7]}$ Stability of the shoulder and the construction were evaluated intraoperatively by direct observation. Excellent fixation was obtained with full range of motion and stability of the left shoulder was similar to the right side. The total operating time was 180 minutes. Perioperative antibiotic prophylaxis with a double dose of a second-generation cephalosporin was administered. Postoperatively, both shoulders were immobilized with external rotation braces for six weeks, followed by passive, active-assisted, and progressively active range of shoulder motion and rotator cuff strengthening exercises for the next six weeks. An internal rotation of the shoulders was not allowed during this period. At 12 weeks postoperatively, full activity was allowed. At 14 months during follow-up, the patient was asymptomatic; both shoulder joints were painless and stable without apprehension or recurrence of instability. The forward flexion was in 110 degree for the left side and in 130 degree for the right side, whereas abduction was in 135 degree for the right shoulder and in 115 degree for the left shoulder. The internal rotation was at L3 level for the left arm and at $\mathrm{T}_{12}$ level for the right arm. Finally, the Constant Shoulder Score was 78 for the left shoulder and 84 for the right shoulder (Figure 3a, b). Radiographs and computed tomography scans showed congruent glenohumeral joints and restoration of the shape of the humeral head (Figure $4 a, b$ and 5a, b).

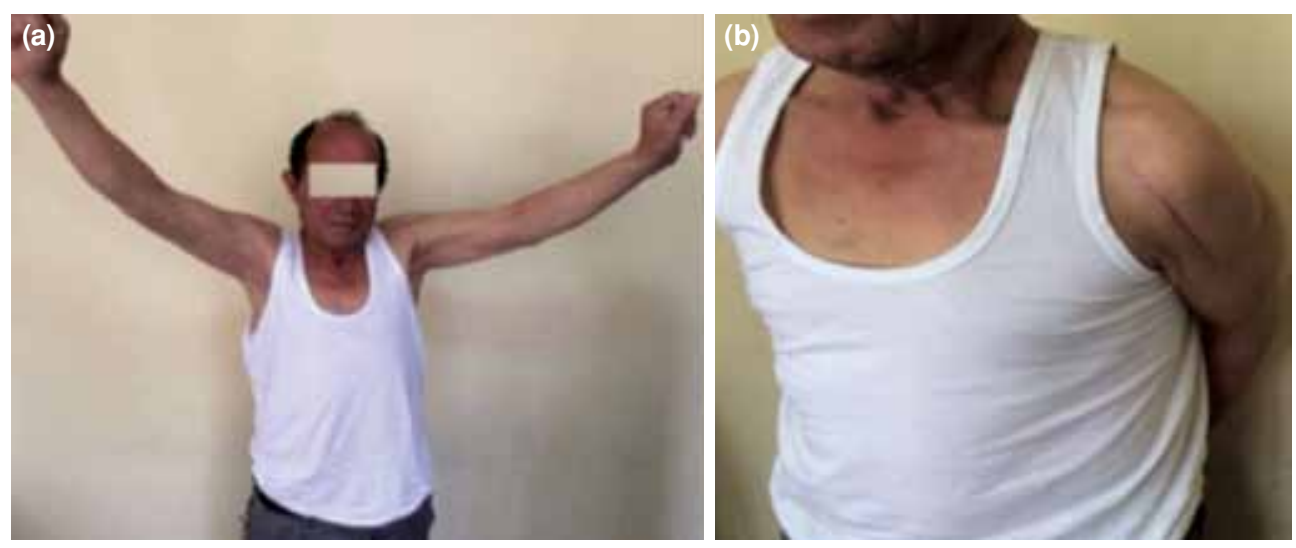

Figure 3. The patient had slight functional restrictions in the both shoulder joints, however, both were painless and stable. (a) He had slight restriction in the left shoulder abduction. (b) Both shoulder rotations were good. 

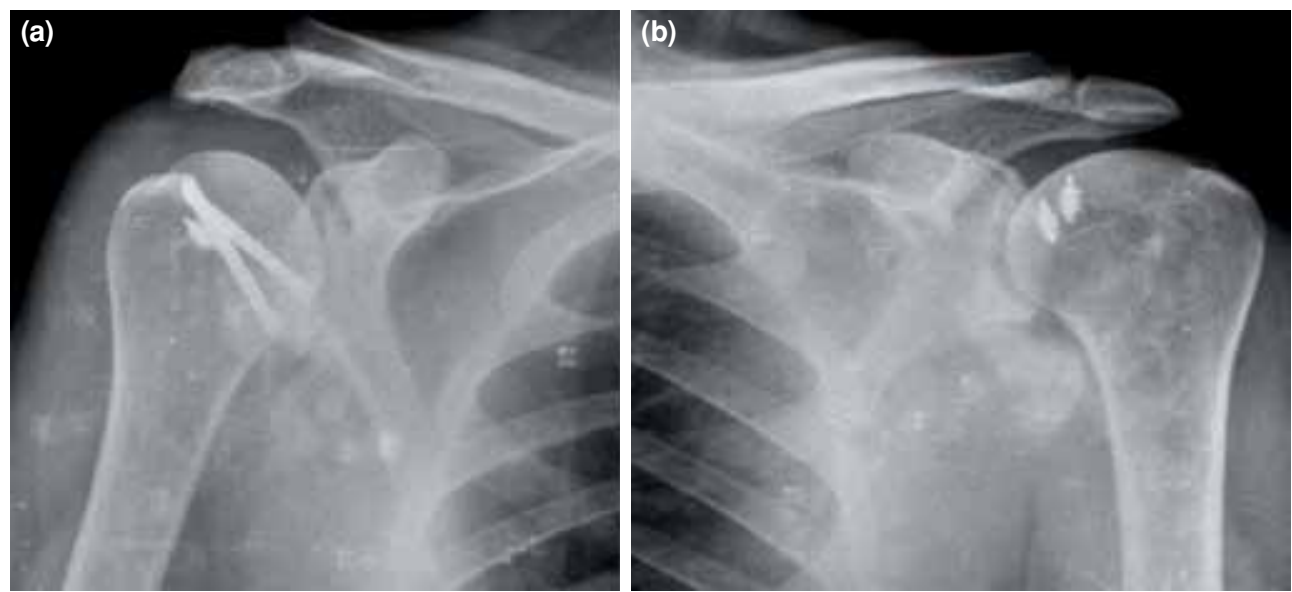

Figure 4. Postoperative anteroposterior radiographs of the both shoulder at nine months showing normal humeral head shape and excellent joint congruency. (a) Allograft reconstruction of humeral head for right shoulder. (b) Transfer of the lesser tuberosity by modified McLaughlin technique for the left side.

\section{DISCUSSION}

The impaction of the anteromedial part of the humeral head is crucial in the treatment of chronic posterior dislocation. McLaughlin ${ }^{[8]}$ recommended transfer of the subscapularis tendon into the defect to prevent recurrence of glenohumeral instability. Hawkins et al. ${ }^{[7]}$ modified the McLaughlin technique suggesting the transfer of the lesser tuberosity with the attached subscapularis tendon for more secure fixation of the tendon into the defect using suture anchors rather than detachment and reattachment of the tendon into the defect.

For the treatment of reverse Hill-Sachs deformities, many contemporary authors have advocated the modified McLaughlin technique for the defects involving as much as $30 \%$ or even $40 \%$ of the humeral head and osteochondral allograft or total or hemiarthroplasty for defects involving more than $40 \%$ of the articular surface. Allograft reconstruction is preferable to arthroplasty in larger defects in relatively younger patients (Table I). ${ }^{[1,7-14]}$

For patients who have good bone quality of the residual head and an absence of relevant osteoarthrosis, reconstruction with an allograft represents a viable alternative to hemiarthroplasty or total joint arthroplasty for carefully selected larger defects. However, our follow-up time was too short to recommend whether avascular necrosis or graft collapse would develop, since posterior bilateral dislocation was usually experienced by middle-aged active males. In conclusion, we suggest that hemior total arthroplasty should be reserved the final treatment of choice.
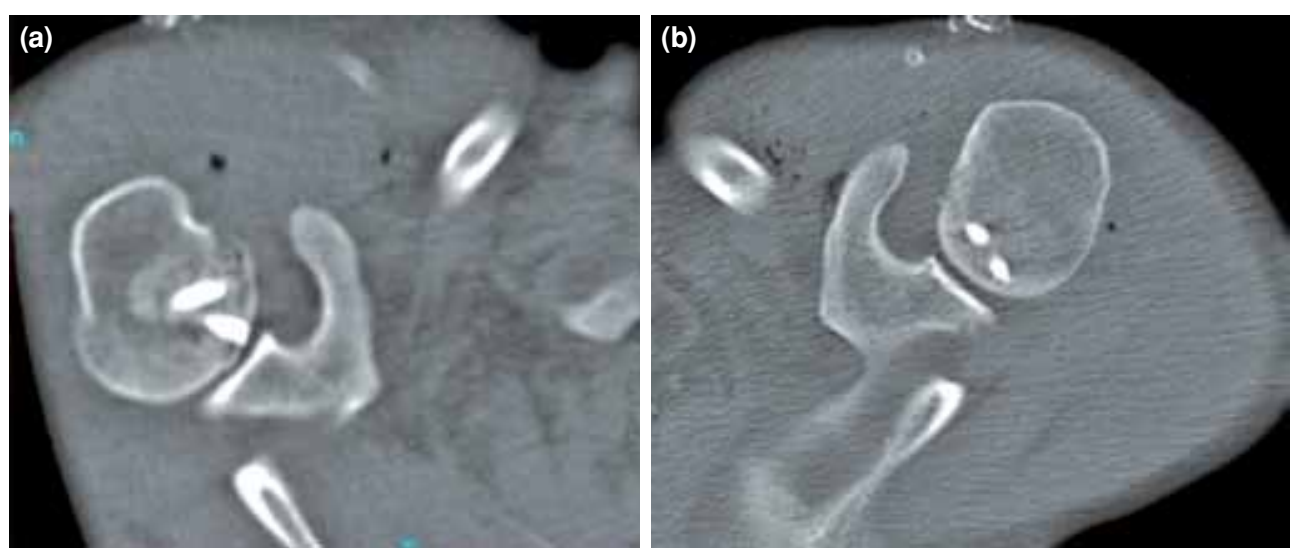

Figure 5. Axial computed tomography scans of the both shoulder demonstrates the well centered humeral head over the glenoid fossa. (a) Right shoulder (b) Left shoulder. 
TABLE I

Literature review for the treatment of locked posterior dislocation of the shoulder

\begin{tabular}{|c|c|c|c|c|c|}
\hline Authors & Number of cases & $\begin{array}{l}\text { Articular surface } \\
\text { defect size }\end{array}$ & Technique & Follow-up & Results \\
\hline Kokkalis et al. ${ }^{[11]}$ & Case report & $\begin{array}{l}\text { One side } 35 \% \text { and the } \\
\text { other side } 40 \%\end{array}$ & $\begin{array}{l}\text { Modified McLaughlin } \\
\text { for both shoulders in } \\
\text { a single stage }\end{array}$ & 22 month & $\begin{array}{l}\text { Both shoulder joints; } \\
\text { painless and stable } \\
\text { without apprehension } \\
\text { or recurrence of } \\
\text { instability. }\end{array}$ \\
\hline Ivkovic et al. ${ }^{[2]}$ & Case report & $\begin{array}{l}\text { One side, of more } \\
\text { than } 50 \% \text { and the } \\
\text { other side, } 40 \% \text {. }\end{array}$ & $\begin{array}{l}\text { Hemiarthroplasty } \\
\text { on one side and } \\
\text { reconstruction of } \\
\text { the head by an } \\
\text { osteochondral } \\
\text { autograft on the other. }\end{array}$ & 36 month & $\begin{array}{l}\text { Clinical and } \\
\text { radiological results, } \\
\text { excellent. }\end{array}$ \\
\hline Gerber et al..$^{[12]}$ & Four patients & $\begin{array}{l}40 \%, 50 \%, 50 \%, 55 \% \\
\text { respectively }\end{array}$ & $\begin{array}{l}\text { Allograft } \\
\text { reconstruction with } \\
\text { femoral head }\end{array}$ & 68 month & $\begin{array}{l}\text { Stability was restored } \\
\text { and maintained in } \\
\text { each patient. }\end{array}$ \\
\hline Kokkalis et al..9] & $\begin{array}{l}\text { Five patients, six } \\
\text { shoulders }\end{array}$ & $\begin{array}{l}\text { Range, } 30 \%-45 \% \text {, } \\
\text { (mean } 38 \% \text { ) }\end{array}$ & Modified McLaughlin & 20 month (15-24) & $\begin{array}{l}\text { All patients, } \\
\text { asymptomatic with } \\
\text { painless and stable } \\
\text { shoulder joints } \\
\text { without apprehension } \\
\text { or recurrence of } \\
\text { instability }\end{array}$ \\
\hline Martínez et al.[14] & Six patients & At least $40 \%$ & $\begin{array}{l}\text { Allograft } \\
\text { reconstruction with } \\
\text { humeral head }\end{array}$ & & $\begin{array}{l}\text { In two of six patients, } \\
\text { the allograft collapsed } \\
\text { over time. }\end{array}$ \\
\hline Torrens et al. ${ }^{[1]}$ & Case report & $50 \%$ in both shoulders & $\begin{array}{l}\text { The osteochondral } \\
\text { autograft obtained } \\
\text { from the left humeral } \\
\text { head for right side } \\
\text { and hemiarthroplasty } \\
\text { for left side. }\end{array}$ & 2 year & $\begin{array}{l}\text { Pain-free and good } \\
\text { mobility in both } \\
\text { shoulders. }\end{array}$ \\
\hline Aparicio et al. ${ }^{[6]}$ & $\begin{array}{l}\text { Six patients, seven } \\
\text { shoulders }\end{array}$ & $\begin{array}{l}\text { In two shoulders } 25 \% \\
\text { and } 30 \%\end{array}$ & $\begin{array}{l}\text { Modified McLaughlin } \\
\text { (for two shoulders) }\end{array}$ & Minimum 2 year & $\begin{array}{l}\text { Functional results, } \\
\text { good in all shoulders }\end{array}$ \\
\hline \multirow[t]{2}{*}{ Hawkins et al..$^{[7]}$} & \multirow[t]{2}{*}{$\begin{array}{l}\text { Forty patients with } 41 \\
\text { shoulder }\end{array}$} & \multirow[t]{2}{*}{$\begin{array}{l}\text { In various sizes } \\
\text { impression defects }\end{array}$} & \multirow{2}{*}{$\begin{array}{l}\text { Closed reduction in } \\
12, \text { transfer of the } \\
\text { subscapularis tendon } \\
\text { in nine, transfer of the } \\
\text { lesser tuberosity in } \\
\text { four, hemiarthroplasty } \\
\text { in nine and total } \\
\text { arthroplasty in ten } \\
\text { shoulders. }\end{array}$} & \multirow[t]{2}{*}{5.5 year } & $\begin{array}{l}\text { Successful in six, } \\
\text { four, four, six and nine } \\
\text { respectively. }\end{array}$ \\
\hline & & & & & $\begin{array}{l}\text { Once the diagnosis } \\
\text { is established, the } \\
\text { majority of patients } \\
\text { with this lesion can } \\
\text { be successfully } \\
\text { managed. }\end{array}$ \\
\hline
\end{tabular}

\section{Declaration of conflicting interests}

The authors declared no conflicts of interest with respect to the authorship and/or publication of this article.

\section{Funding}

The authors received no financial support for the research and/or authorship of this article.

\section{REFERENCES}

1. Şanel S, Şencan S, Öçgüder A, Solakoğlu C. Bilateral, locked, recurrent anterior shoulder dislocation: case report. Eklem Hastalik Cerrahisi 2015;26:52-5.

2. Ivkovic A, Boric I, Cicak N. One-stage operation for locked bilateral posterior dislocation of the shoulder. J Bone Joint Surg [Br] 2007;89:825-8.

3. Kelly JP. Fractures complicating electro-convulsive therapy and chronic epilepsy. J Bone Joint Surg [Br] 1954;36:70-9.

4. Bock P, Kluger R, Hintermann B. Anatomical reconstruction for Reverse Hill-Sachs lesions after posterior locked shoulder dislocation fracture: a case series of six patients. Arch Orthop Trauma Surg 2007;127:543-8.

5. Hatzis N, Kaar TK, Wirth MA, Rockwood CA Jr. The often overlooked posterior dislocation of the shoulder. Tex Med 2001;97:62-7.

6. Aparicio G, Calvo E, Bonilla L, Espejo L, Box R. Neglected traumatic posterior dislocations of the shoulder: controversies on indications for treatment and new CT scan findings. J Orthop Sci 2000;5:37-42.

7. Hawkins RJ, Neer CS, Pianta RM, Mendoza FX. Locked posterior dislocation of the shoulder. J Bone Joint Surg Am 1987;69:9-18.

8. McLaughlin HL. Posterior dislocation of the shoulder. J Bone Joint Surg [Am] 1952;24:584-90.

9. Kokkalis ZT, Mavrogenis AF, Ballas EG, Papanastasiou J, Papagelopoulos PJ. Modified McLaughlin technique for 
neglected locked posterior dislocation of the shoulder. Orthopedics 2013;36:912-6.

10. Cheng SL, Mackay MB, Richards RR. Treatment of locked posterior fracture-dislocations of the shoulder by total shoulder arthroplasty. J Shoulder Elbow Surg 1997;6:11-7.

11. Kokkalis ZT, Mavrogenis AF, Ballas EG, Papagelopoulos PJ, Zoubos AB. Bilateral neglected posterior fracturedislocation of the shoulders. Orthopedics 2012;35:1537-41.

12. Gerber C, Lambert SM. Allograft reconstruction of segmental defects of the humeral head for the treatment of chronic locked posterior dislocation of the shoulder. J Bone Joint Surg [Am] 1996;78:376-82.

13. Delcogliano A, Caporaso A, Chiossi S, Menghi A, Cillo M, Delcogliano M. Surgical management of chronic, unreduced posterior dislocation of the shoulder. Knee Surg Sports Traumatol Arthrosc 2005;13:151-5.

14. Martinez AA, Calvo A, Domingo J, Cuenca J, Herrera A, Malillos M. Allograft reconstruction of segmental defects of the humeral head associated with posterior dislocations of the shoulder. Injury 2008;39:319-22. 